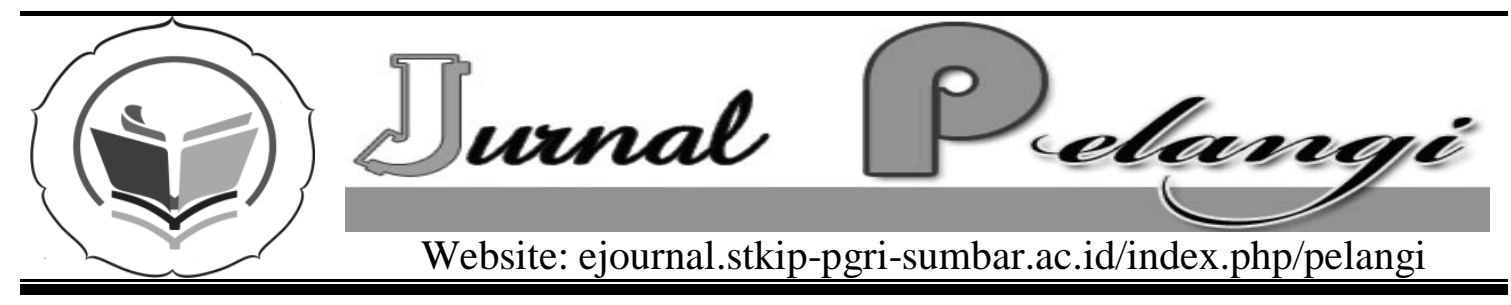

\title{
PENERAPAN MODEL GROUPING INVESTIGATION UNTUK MENINGKATKAN KETERAMPILAN BERPIKIR KRITIS MAHASISWA UMMY SOLOK DALAM MATA KULIAH EVALUASI PEMBELAJARAN MATEMATIKA
}

\author{
Yulyanti Harisman
}

INFO ARTIKEL

Diterima:

Direview:

Disetujui:

Keywords:

peningkatan, kemampuan, berpikir kritis, matematika, UMMY Solok

\begin{abstract}
The capability of thinking critically of the students of UMMY Solok is still low on the subject Evaluasi Pembelajaran Matematika. From the previous research on this matter, the students tended to be passive on the process of learning in class, as the impact most of the students was still not able in collecting, analyzing, synthesizing the objects of the lesson, drawing conclusion from the object of the lesson, assessing and correcting the objects of the lesson with the right argumentation, and to solve the problem on the objects of the lesson. This research is aimed at improving the capability of the students through the learning cooperatively with the model of Grouping Investment. Identification of the problem in this research is can the model of learning Grouping Investigation improve the skill of thinking critically of the students of UMMY Solok seen from the indicator of capability of collecting, analyzing, synthesizing the objects of the lesson, capability of drawing the conclusion of the object of the lesson, correcting and assessing the objects of the lesson, and the capability of solving the problem on the objects of the lesson. This research is the mixing of the action research and class action research. Before conducting the class action research, the researcher doing some actions. The action research is integrated wholly to the class action research, so that this step is believed as a continuity process. The subject of this research is the students of fifth semester with the total of 35 students. The data is collected through observation sheet, problem design, field notes, and interview. The data is analyzed by simple percentage and described by descriptive analysis. The results of the research show that the learning using the model of Grouping Investigation can improve the skill of thinking
\end{abstract}


critically of the students on the subject Evaluasi Pembelajaran Matematika. The improvement is shown by $100 \%$ of the students is good at collecting the objects of the lesson, $71.43 \%$ of the students is good at synthesizing the objects of the lesson, $85.71 \%$ of the students is good at analysing the objects of the lesson, $83,71 \%$ of the students is good at drawing the conclusion of the objects of the lesson, $83.33 \%$ of the students is good at correcting the objects of the lesson, and $74.19 \%$ of the students is good at solving the problem. This shows that the model of grouping Grouping Investigation can improve the skill of think critically of the students of UMMY Solok on the subject of Evaluasi Pembelajaran Matematika.

\section{PENDAHULUAN}

Evaluasi

Matematika adalah salah satu mata kuliah wajib untuk mahasiswa Jurusan Pendidikan Matematika. Pada mata kuliah ini, mahasiswa dipersiapkan menjadi calon pendidik yang baik. Calon pendidik yang mampu mengetahui, merancang, dan menyelesaikan soal dengan berbagai tingkat kesulitan yang sesuai dengan beberapa ranah pengetahuan, serta merancang soal yang tepat untuk mengakses kemampuan matematis siswa. Soal tersebut mencakup semua materi pembelajaran matematika disetiap jenjang pedidikan, mulai dari SD, SMP, dan SMA

Hal yang diharapkan dari mahasiswa UMMY Solok yang sudah mengikuti perkuliahan Evaluasi Pembelajaran Matematika, mereka harus mampu mengusai seluruh materi sesuai dengan kompetensi dasar dari mata kuliah ini.

Pada kenyaataannya sebagian besar dari mahasiswa tidak mampu memahami dan menerapkan apa yang menjadi tuntutan dari mata kuliah ini. Mahasiswa cenderung kebingungan dalam merancang dan menyelesaikan soal pada beberapa ranah pengetahuan walaupun sudah diajarkan.

\begin{abstract}
Pemahaman mahasiswa yang kurang baik terhadap materi perkuliahan matematika juga diperlihatkan dari rendahnya nilai mahasiswa pada mata kuliah ini. Sebagai gambaran rendahnya nilai mahasiswa dapat dilihat pada tabel 1 berikut:
\end{abstract}

Tabel 1. Nilai Ujian Mahasiswa Semester V Tahun Ajaran 2009/2010 pada Mata Kuliah Evaluasi Pembelajaran Matematika

\begin{tabular}{|c|c|c|c|}
\hline No & $\begin{array}{c}\begin{array}{c}\text { Klasifikasi } \\
\text { Nilai }\end{array} \\
\end{array}$ & $\begin{array}{c}\text { Frekuensi } \\
\text { (f) }\end{array}$ & Presentase $(\%)$ \\
\hline 1 & $\mathrm{~A}$ & 2 & 6,25 \\
\hline 2 & $\mathrm{~B}$ & 5 & 15,62 \\
\hline 3 & $\mathrm{C}$ & 12 & 37,5 \\
\hline 4 & D & 13 & 40,63 \\
\hline \multicolumn{2}{|r|}{ Total } & 32 & 100 \\
\hline
\end{tabular}

Permasalahan di atas menunjukan adanya kesenjangan anatara realita dilapangan dengan kodisi yang diharapkan. Nilai mahasiswa masih berpusat pada nilai C dan D. Hal ini disebabkan karena mahasiswa yang mengikuti mata kuliah ini cenderung tidak kritis. Mahasiswa tidak mau ikut terlibat dalam perencanaan perkuliahan. Mahasiswa cenderung ingin memeperoleh seluruh materi dari dosen dan malas untuk memiliki buku sumber, memecahkan 
masalah, menganalis materi, mensintesis materi, dan menyimpulkan materi

$$
\text { Sedikitnya persentase }
$$

mahasiswa yang sudah berpikir kritis menyebabkan perkulihan cenderung berjalan kaku dan monoton. Proses belajar bersifat satu arah tanpa adanya feedback dari mahasiswa untuk bertanya, padahal dalam perkuliahan diharapkan adanya ide-ide yang kritis dari mahasiswa untuk menciptakan diskusi yang hangat mengenai konsep suatu materi. Penyebab tidak kritisnya mahasiswa pada perkuliahan Evaluasi Pembelajaran Matematika adalah kemampuan kognitif mahasiswa masih rendah, dosen hanya melihat hasil kerja mahasiswa tanpa memperhatikan proses, buku sumber yang dimiliki mahasiswa masih kurang karena belum lengkapnya fasilitas pustaka di UMMY Solok.

$$
\text { Upaya yang dilakukan }
$$

dosen, dosen sudah memberikan model tugas terstruktur dan kuis, dosen juga sudah menerapkan model pemebelajaran kooperatif dan presetasi, tetapi belum teroganisir dengan baik dengan rancangan masalah yang belum jelas. Dosen hanya meminta kelompok yang tampil sebagai penanggung jawab pada materi yang telah dibagikan, sedangkan kelompok lain hanya datang sebagai pendengar dan datang tampa persiapan dari rumah, sehingga materi diskusi hanya dikuasai oleh kelompok yang tampil saja.

Usaha tersebut ternyata belum berhasil dalam mengembangkan dan mengasah kemampuan berpikir kritis mahasiswa. Dengan demikian, dosen perlu merencanakan, mengatur, mengarahkan dan mengevaluasi lagi suatu mekanisme pembelajaran yang lebih baik, misalnya model apa yang harus dipakai untuk mengajar, alat- alat apakah yang dibutuhkan mahasiswa untuk mencapai tujuan yang telah ditetapkan.

Berdasarkan pengalaman peneliti mengajar pada mata kuliah Evaluasi Pembelajaran Matematika yang telah diuraikan sebelumnya, peneliti beranggapan bahwa masalah yang dihadapi disebabkan karena model pengajaran belum tepat. Oleh karena itu, peneliti mencoba menerapkan model Grouping investigations untuk mengatasi masalah pada perkuliahan ini. Menurut Kinarwati (2007: 59) "model grouping investigation merupakan suatu model yang terdiri dan enam langkah yaitu: “
(1) Grouping,
(2) Planing,

Investigating,

(4) Organizing,

Presenting, (6) Evaluating “.

Model

grouping investigation sangat relevan untuk mengatasi masalah kurang kritisnya mahasiswa pada mata kuliah ini, karena model ini melibatkan mahasiswa mulai dari tahap awal perkulihan sampai akhir perkuliahan. Mahasiswa dilibatkan mulai dari pengumpulan materi, menganalisis materi, mensintesis materi, memecahkan masalah sampai pada tahap pengevaluasian.

Berdasarkan uraian di atas peneliti tertarik untuk melakukan penelitian dengan judul "Penerapan Model Grouping Investigation untuk Meningkatkan Keterampilan Berpikir Kritis Mahasiswa UMMY Solok dalam Mata Kuliah Evaluasi Pembelajaran Matematika”. 


\section{METODE PENELITIAN}

Penelitian ini adalah gabungan dari Penelitian Tindakan (action research) dan Penelitian Tindakan Kelas (Classroom action research). Pelakasanaan terdiri dari perencanaan, pelaksanaan, observasi, refleksi. Data dianalisis dan dijelaskan secara deskriptif dan kuantitatif.

\section{Tabel 2. Tabel Pengskoran Indikator Berpikir Kritis}

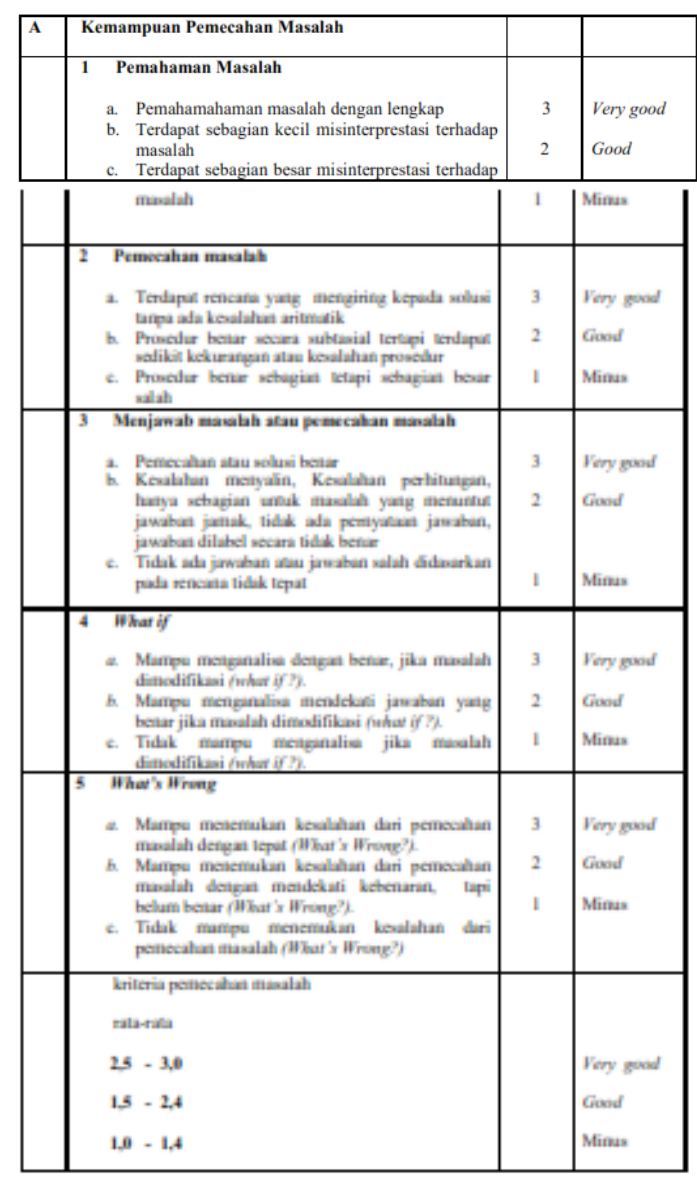

Pengumpulan data dilakukan melalui empat prosedur yaitu sebagai berikut ini:

1. Pemberian masalah, responden atau kelompok diberikan kebebesan dalam menyampaikan pendapatnya yang berkaitan masalah.

2. Pemberian waktu untuk memahami dan menyusun pokok pembahasan yang dimulai baik di kelas dan memberi waktu selama satu minggu, untuk penampilan diskusi dilakukan secara acak. Waktu presentasi diberikan selama satu SKS dari jumlah dua SKS mata kuliah.

3. Peneliti merekam pembicaraan, mengamati yang terjadi saat presentasi dan mengumpulkan makalah yang dibuat oleh mahasiswa.

4. Penyusunan transkrip rekaman, peneliti mentranskrip hasil rekaman yang akan dianalisis serta menganalisis makalah yang telah dibuat oleh mahasiswa sesuai dengan rumusan permasalahan penelitian.

5. Memberikan soal pemecahan masalah kepada mahasiswa setelah diskusi kelopok untuk dianalisa.

6. Memakai catatan lapangan untuk mencatat semua kejadian.

Memasukan bahan-bahan yang akan dianalisis kealam tabel observasi

\section{A. Penilaian}

Data yang diperoleh dari hasil analisis dengan menggunakan rubrik pengskoran dihitung dengan dengan persentase sederhana berikut:

$$
\mathrm{P}=\times 100 \%
$$

$\mathrm{P}$ : presetase mahasiswa yang bertaraf (Very Good, Good, Minus)

$\mathrm{F}$ : Banyak mahasiswa yang bertaraf (Very Good, Good, Minus) N :

Jumlah seluruh mahaiswa

Indikator dikatakan tercapai jika $75 \%$ dari seluruh mahasiswa atau 26 orang dari 35 orang sudah menduduki taraf Very Good atau Good. 


\section{HASIL DAN PEMBAHASAN}

A. Siklus I

1. Deskripsi indikator berpikir kritis

Tabel 3. Data indikator kemampuan berpikir kritis untuk penilaian individu

\begin{tabular}{|l|l|c|c|c|}
\hline \multirow{2}{*}{$\begin{array}{c}\text { Indikator untuk } \\
\text { kemampuan berpikir } \\
\text { kritis }\end{array}$} & \multirow{2}{*}{ Nilai } & \multicolumn{3}{|c|}{ Pertemuan } \\
\cline { 3 - 5 } & & $\mathbf{1}$ & $\mathbf{2}$ & $\mathbf{3}$ \\
\hline $\begin{array}{l}\text { Kemampuan } \\
\text { pemecahan masalah }\end{array}$ & Very Good & & $48,58 \%$ & $65,71 \%$ \\
\cline { 2 - 5 } & Good & & $25,71 \%$ & $20,00 \%$ \\
\cline { 2 - 5 } & Minus & & $25,71 \%$ & $14,29 \%$ \\
\hline
\end{tabular}

\section{a. Kemampuan Pemecahan Masalah}

Pada kemampuan pemecahan masalah aspek yang dinilai adalah: pemahaman masalah, pemecahan masalah, menjawab masalah dari pemecahan masalah, inisiatif mahasiswa jika soal dirobah atau dimodifikasi (what if ), menemukan apa yang salah dari pertanyaan soal (what wrong)

\section{i) Pemahaman Masalah}

Untuk pertemuan pertama, aspek ini belum bisa dimunculkan karena pada pertemuan ini, baru membahas pengantar mata kuliah evaluasi. Pada pertemuan kedua, aspek ini dimunculkan dengan meminta mahasiswa untuk mengklasifikasikan soal kedalam ranah kognitif pada taksonomi Bloom. Untuk pertemuan kedua ini, seluruh mahasiswa sudah bertaraf Very Good. Berikut ini akan diperlihatkan cuplikan kerja mahasiswa sudah bertaraf Very Good.

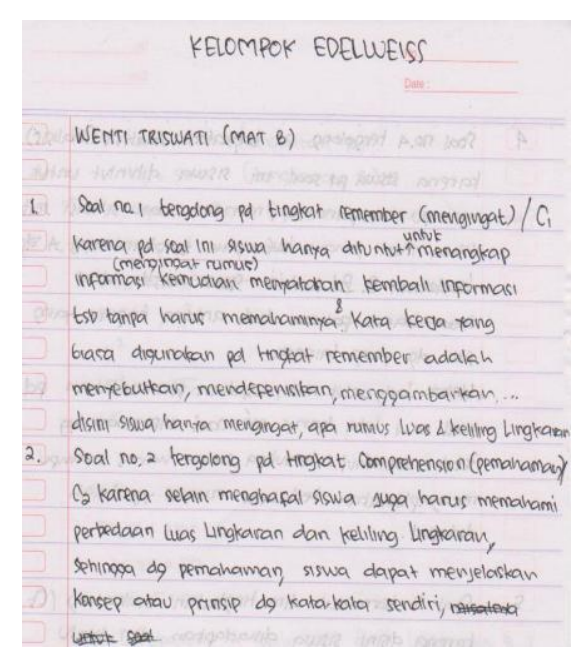

Terlihat dari hasil kerjanya, dia sangat paham dalam mengklasifikasikan soal yang diberikan dosen kedalam ranah kognitif taksonomi Bloom dengan alasan yang benar. Hal ini menunjukan bahwa model Grouping Investigations sangat ampuh untuk mengasah kemampuan pemahaman masalah mahasiswa.

Selanjutnya untuk pertemuan ketiga, ada beberapa mahasiswa yang bertaraf minus untuk aspek ini, hal ini disebabkan karena materinya agak sulit.

.Berdasarkan catatan lapangan diperoleh faktor yang menyebabkan mahasiswa belum mampu melakukan pemahaman masalah dengan lengkap adalah kerena mereka sering tidak hadir dalam diskusi kelompok. Usaha yang dilakukan dosen adalah meminta anggota kelompok yang paham, untuk membatu teman mereka yang kesulitan, kemudian memberikan tugas tambahan kepada mahasiswa yang tidak hadir dalam diskusi kelompok. Berikut ini akan ditampilkan cuplikan dari pemecahan masalah oleh mahasiswa yang dianggap paham pada aspek pemahaman masalah dan sudah dikategorikan mahasiswa yang 
bertaraf Very Good pada pertemuan ketiga.

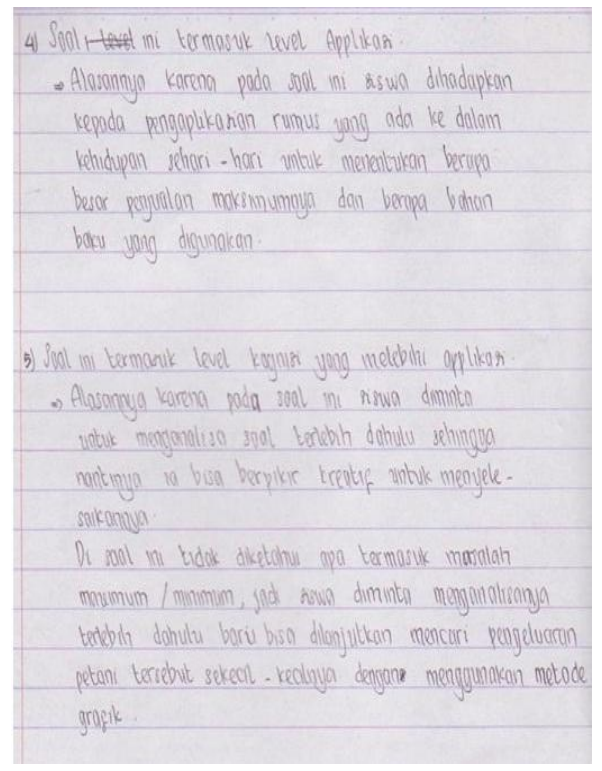

\section{ii) Pemecahan Masalah}

Pada aspek pemecahan masalah, hal yang dijadikan penilaian adalah bagaimana mahasiswa merencanakan pemecahan masalah yang mengiring pada solusi yang benar tanpa ada kesalahan aritmatik untuk mahasiswa yang bertaraf Very Good, dan terdapat prosedur yang benar, tetapi terdapat sedikit kekurangan atau kesalahan prosedur untuk mahasiswa yang bertaraf Good. Untuk mahasiswa yang bertaraf minus prosedur sebagian benar tetapi sebagian besar prosedur salah.

Pada pertemuan pertama aspek ini tidak dapat dimunculkan, karena pada pertemuan ini masih membahas tentang definisi evaluasi. Pada aspek ini penilaian diberikan dengan melihat langkah-langkah atau prosedur yang dibuat oleh mahasiswa dalam mencari jawaban soal. Untuk pertemuan kedua ini, umumnya mahasiswa sudah bertaraf Very Good dan Good. Namun, masih ada beberapa mahasiswa yang mengerjakan soal dengan prosedur yang digunakan sebagian besar salah.

\section{iii)Menjawab Masalah Dari}

Pemecahan Masalah

Pada aspek ini hal yang menjadi patokan penilaian adalah pemecahan atau solusi benar untuk mahasiswa yang bertaraf Very Good, Kesalahan menyalin, kesalahan perhitungan untuk mahasiswa yang bertaraf Good, dan tidak ada jawaban atau jawaban salah untuk mahasiswa yang bertaraf minus. Untuk pertemuan pertama, aspek ini juga belum dapat dimunculkan, karena materi awal masih membicarakan tentang definisi, manfaat, prinsip-prinsip evaluasi.

\begin{tabular}{lccr}
\multicolumn{2}{c}{ Untuk } & pertemuan & kedua, \\
hampir & setiap & mahasiswa & sudah \\
mampu & menjawab & soal & dengan \\
solusi & yang & benar, & yang
\end{tabular}
dimunculkan pada saat mahasiswa. Sebagian besar mahasiswa sudah mampu memberikan solusi dan jawaban yang benar dalam waktu yang sangat cepat, karena pemecahan masalah diberikan pada saat 20 menit terakhir perkuliahan, hal ini juga akan mengasah Quickning of Mind dari mahasiswa. Namun, masih ada mahasiswa yang salah dalam memberikan solusi. Terbatasnya waktu yang diberikan dalam membuat pemecahan masalah, membuat mahasiswa yang kurang belajar akan kewalahan dalam pemecahan masalah. Hal ini disebabkan, karena materi harus dipelajari sendiri dan dianalisis sendiri bersama kelompok tanpa ada penjelasan oleh dosen. Untuk pertemuan ketiga, setiap mahasiswa sudah ikut dalam mendiskusikan materi yang ditetapkan pada rancangan masalah. iv)Inisiatif Mahasiswa Jika Soal Di Ubah Atau Dimodifikasi (What If ) 
\begin{tabular}{lcr}
\multicolumn{1}{r}{ Pada } & aspek ini, & hal yang \\
dinilai & adalah & bagaimana \\
kemampuan & mahasiswa dalam \\
menganalisa & dengan benar, jika \\
masalah dimodifikasi. & Untuk
\end{tabular} pertemuan pertama, aspek ini juga belum bisa dimunculkan. Untuk pertemuan kedua, aspek ini dimunculkan dengan meminta mahasiswa untuk mengerjakan soal yang dirancang yang memunculkana aspek tersebut, dimana mahasiswa diminta untuk menentukan rumus luas lingkaran jika keliling diketahui dan menentukan rumus keliling jika rumus luas lingkaran diketahui. Hampir setiap mahasiswa tidak mampu menganalisa masalah ini dengan cepat, banyak mahasiswa yang berdiam diri pada saat mengerjakan pemecahan masalah yang memunculkan aspek ini. Hal ini disebabkan karena mahasiswa tersebut kesulitan dalam menemukan ide awal untuk menyelesaikan masalah tersebut, bahkan ada beberapa mahasiswa yang tidak ingat lagi apa rumus keliling dan luas lingkaran, padahal pada rancangan masalah dosen sudah memberitaukan materi apa yang akan dijadikan topik pada tiap pertemuan.

Faktor yang menyebabkan mahasiswa tidak mampu pada aspek ini adalah mahasiswa tidak mau berusaha mempelajari materi bersama kelompok. Untuk mengatasi masalah ini dosen juga meminta anggota kelompok yang telah mampu memahami materi dengan baik untuk membantu mahasiswa yang masih bingung serta pemalas dan kurang termotivasi untuk belajar dan mengembangkan kemampuan mereka pada aspek ini untuk pertemuan selanjutnya. Berikut bentuk hasil kerja mahasiswa.

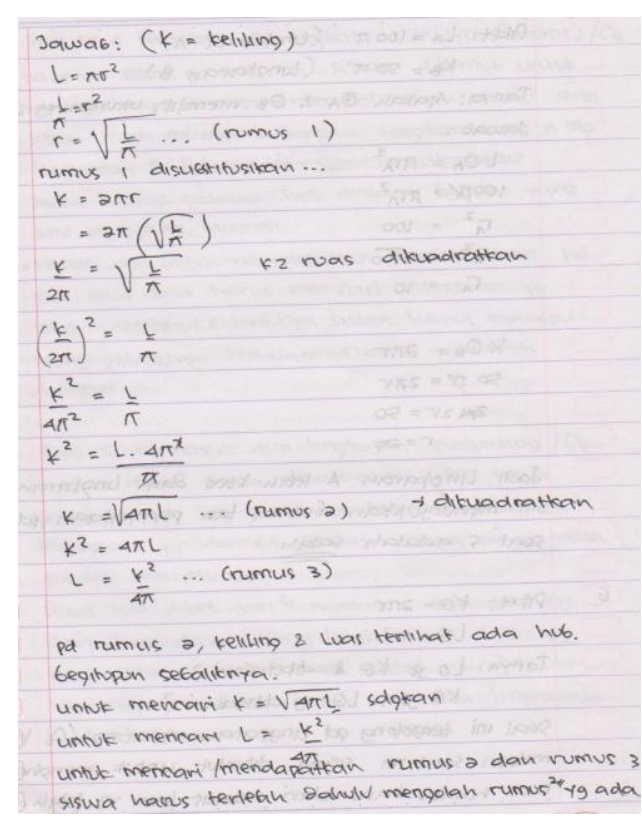

Terlihat dari hasil kerja dia telah mampu menganalisa masalah dengan benar, diharapkan untuk pertemuan selanjutnya setiap mahasiswa sudah menduduki taraf Very Good pada aspek "What if". Pada pertemuan ketiga, hampir setiap mahasiswa tidak kesulitan lagi dalam menganalisa. Mahasiswa diminta untuk menganalisa apakah suatu masalah termasuk ke dalam masalah maksimum atau masalah minimum. Masalah tersebut sebelumnya telah dimodifikasi dahulu dari masalah yang seharusnya merupakan masalah maksimum, menjadi seolah- olah masalah adalah kasus minimum.

\section{v) Menemukan Apa Yang Salah Dari Pertanyaan Soal (What's Wrong)}

Pada aspek ini mahasiswa harus mampu menemukan kesalahan dari pernyataan soal dengan benar. Pada pertemuan pertama, apek ini juga belum bisa dimunculkan. Pada pertemuan kedua aspek ini dimunculkan dengan meminta mahasiswa mengerjakan soal yang telah disediakan. Hampir setiap mahasiswa tidak kesulitan dalam 
memahami aspek ini, dimana setiap mahasiswa sudah mampu mengungkapkan bahwa pernyataan soal no 5 yang menyatakan bahwa lingkaran A dan lingkaran B adalah dua lingkaran dengan ukuran yang sama adalah salah. Namun, masih ada beberapa mahasiswa yang tidak mampu mengemukakan hal tersebut. Contoh hasil kerja salah satu mahasiswa yang sudah bertaraf Very Good pada aspek ini.

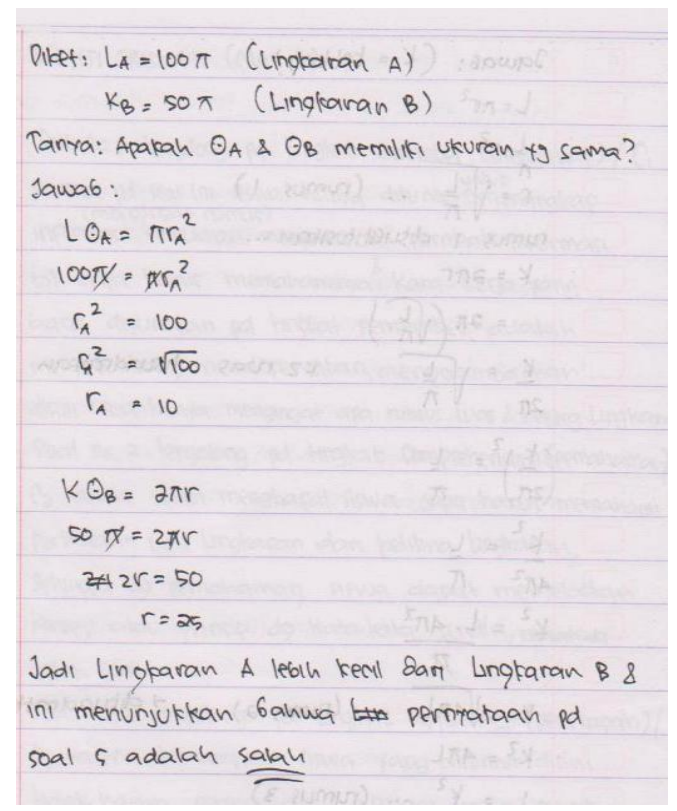

Selanjutnya dengan membagi point yang diperoleh pada masingmasing aspek dengan banyak aspek, diperoleh persentase mahasiswa yang bertaraf Very Good sebanyak 48,58\%, $25,71 \%$ yang bertaraf Good, dan $25,75 \%$ mahasiswa masih bertaraf minus pada pertemuan dua. Selanjutnya dengan melakukan usaha-usaha yang telah diuraikan sebelumnya terjadi peningkatan persentase kelompok yang bertaraf Very Good adalah 65,71\%, 20,00\% mahasiswa yang bertaraf Good dan 14,29 \% mahasiswa masih bertaraf minus. Persentase ini sudah mencapai indikator keberhasilan pada siklus I.

\section{B. Siklus II}

Tabel 4. Data indikator kemampuan berpikir kritis untuk penilaian individu

\begin{tabular}{|c|c|c|c|c|c|}
\hline \multirow[t]{2}{*}{ No. } & \multirow{2}{*}{$\begin{array}{l}\text { Indikator untuk } \\
\text { kemampuan } \\
\text { individu }\end{array}$} & \multirow[t]{2}{*}{ Nilai } & \multicolumn{3}{|c|}{ Pertemuan } \\
\hline & & & 1 & 2 & 3 \\
\hline \multirow[t]{3}{*}{ A } & \multirow{3}{*}{$\begin{array}{l}\text { Kemampuan } \\
\text { pemecahan masalah }\end{array}$} & Very Good & $48,39 \%$ & - & $74,19 \%$ \\
\hline & & Good & $29,03 \%$ & - & $16,13 \%$ \\
\hline & & Minus & $22,58 \%$ & - & $9,68 \%$ \\
\hline \multicolumn{3}{|c|}{ Jumlah siswa yang hadir } & 31 & 30 & 31 \\
\hline
\end{tabular}

1. Deskripsi Indikator Bepikir Kritis

a. Kemampuan Pemecahan Masalah

Pada kemampuan pemecahan masalah aspek yang dinilai adalah: pemahaman masalah, pemecahan masalah, jawaban dari pemecahan masalah, what if, dan What Wrong.

\section{i) Pemahaman Masalah}

Pada aspek ini hal yang diharapkan dari hasil kerja mahasiswa adalah pemahaman masalah mahasiswa sudah lengkap, berikut bentuk hasil kerja mahasiswa

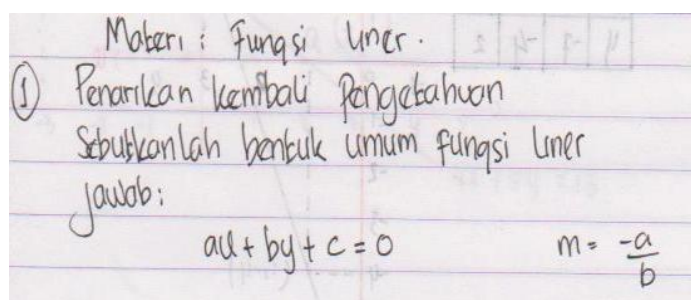

ii) Pemecahan Masalah

Pada siklus dua untuk setiap pertemuan sudah bagus.

iii)Menjawab Masalah

Pada aspek ini hal yang menjadi patokan penilaian adalah pemecahan atau solusi benar untuk mahasiswa yang bertaraf Very Good, Kesalahan menyalin, kesalahan perhitungan untuk mahasiswa yang bertaraf 
Good, dan tidak ada jawaban atau jawaban salah untuk mahasiswa yang bertaraf minus. Sudah sangat sedikit presentase siswa yang bertaraf minus.

iv) What if

Pada aspek ini, hal yang
dinilai $\begin{array}{r}\text { adalah } \\ \text { bagaimana }\end{array}$
kemampuan dalam
menganalisa dengan benar, jika
masalah dimodifikasi. Untuik satu dan
dua tidak dapat dimunculkan. Untuk
pertemuan pada materi realibilitas dan
validitas hapir seluruh siswa mampu
mengungkapkan pengaruh
perpanjangan item soal terhadap
validitas dan realibilitas.

v) What Wrong's

Pada siklus dua hapir seluruh siswa mampu melihat kesalahan soal yang telah dimanipulasi oleh dosen. Berikut contoh hasil kerja siswa:

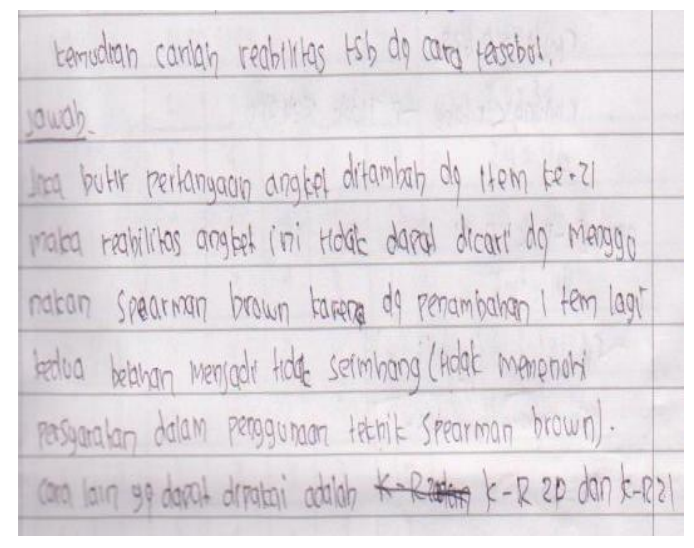

Mahasiswa

mampu

mengemukan ide, bahwa jika item pertanyaan angket ganjil, maka reabilitas angket tidak dapat dicari dengan rumus Spearman Brwon belah dua awal-akhir dan belah dua ganjil, tapi dapat dicari dengan rumus K-R20 dan K-R 21. Hasil yang diperoleh pada aspek ini tidak terlepas dari usaha dosen

\section{KESIMPULAN DAN SARAN}

\author{
Model Grouping \\ investigatios dapat meningkatkan \\ kemampuan berpikir kritis \\ mahasiswa UMMY Solok, dengan \\ meningkatkan seluruh indikator \\ berpikir kritis yaitu:
}

Model Grouping investigations dapat meningkatkan berpikr kritis mahasiswa UMMY Solok daya pemecahan masalah mahasiswa UMMY Solok pada indikator pemahaman masalah, pemecahan masalah, jawaban dari pemecahan masalah, what if, dan What Wrong.

\section{DAFTAR PUSTAKA}

Arikunto, Suharsimi, 1986. Dasardasar Evaluasi Pendidikan. Jogjakarta: Bumi Aksara.
----------, 2006. Prosedur Penelitian Suatu Pendekatan Praktik. Jakarta: PT. Rieneka Cipta -,dkk, 2008. Penelitian Tindakan Kelas. Jakarta: Bumi Aksara.
Aulia, Kinarwati. 2007. Model Pembelajaran Koperatif. Jakarta: Rineka Cipta

Bahri, Syaiful, 2005. Guru dan Anak Didik . Jakarta: Rineka Cipta.

Departemen Pendidikan Nasional, 2006. Permen DIKNAS No.22 Tahun 2006 tentang Standar Isi. Jakarta: Direktorat Jendral Perguruan Tinggi Depdiknas. Depdikbud, 1993. Kurikulum Pendidikan Dasar. Jakarta: Depdikbud. Depdiknas, 2002. Kamus Besar Bahasa 
Indonesia. Jakarta: Balai Pustaka

Fakultas Pasca Sarjana, 2009. Buku Panduan Penulisan Tesis dan Disertasi. Padang: Universitas Negeri Padang.

Harsanto, Ratno. 2005. Cara Berpikir Kreatif dan Kritis. Jakarta: PT. Raja Grafindo

Persada

Hassoubah, Zaleihazhab. 2004.

Developing Creatif \& Critical Thingking Skill. Terjemahan Bambang Suriadi. Bandung: Nuansa

Lufri, 2008. Penelitian Tindakan Kelas dan Penelitian Pengembangan. Padang: Universitas Negeri Padang.

Madya, Suwarsih. 2007. Penelitian Tindakan. Yogyakarta: Alfabeta Maryunis, Aleks, 2004. Metode Pemetaan Informasi Dalam Proses Belajar Matematika di SMA. Disertasi tidak diterbitkan. Jakarta : IKIP Jakarta.

Medsker, Karen L. 2001. Model and Strategies for Training Design. United State of

America: International Society Foe Performance Improvement.

Modul Diklat Calon Widyaiswara, 2007. Penelitian Tindakan Kelas. Jakarta: Lembaga

Administrasi Negara Republik Indonesia.

Muliyardi, 2003. Strategi Pembelajaran Matematika. Padang: UNP.

Sadirman, A.M, 1986. Interaksi dan Motivasi Belajar Mengajar. Jakarta: PT Grafindo

Persada

---------, 2007. Interaksi dan Motivasi Belajar Mengajar. Jakarta: PT Raja Grafindo Persada.
Soleh, Muhammad. 1998. Motivasi Belajar Mengajar. Jakarta: PT Grafindo Persada 